\title{
SOME LINGUISTIC SUGGESTIONS IN CONDUCTING MALAY LANGUAGE CLASSES
}

\author{
KENICHI NAMAI*
}

\begin{abstract}
Despite some skeptics, most foreign language teachers, especially those of English as a Foreign Language (EFL)/English as a Second Language (ESL), advocate Communicative Language Teaching (CLT) and have long been conducting student-centered communicative activities in their classrooms. This paper argues that CLT is generally ineffective in teaching quiet students and students with little motivation. In the context of teaching Malay as a foreign language, it introduces an alternative teaching approach that requires teacher-centered drill activities, which have been shown effective in EFL teaching in Japan, a country known for its typically quiet students, most of whom do not see a point in acquiring any practical skills of English. The paper demonstrates the necessity of explaining basic syntactic rules, some of which tend to be taken for granted, that are crucial in helping students of Malay develop a systematic grammar of their target language.
\end{abstract}

Keywords: English education; Communicative language teaching; Japan; Grammar

\section{INTRODUCTION}

Communicative Language Teaching (CLT) has been the norm in English education in many countries (Bax 2003), and this student-centered language pedagogy has been popular in teaching other languages as well. However, this approach has faced a serious problem in countries like Japan, where students are expected, for various cultural reasons, to attentively listen to their teacher without uttering a single word. For the majority of Japanese citizens, there are still no good reasons to acquire any practical skills of foreign languages, so it is not surprising that most Japanese students do not take CLT activities in English classes seriously. This creates an unfortunate "TENOR" (Abbot 1981) situation for English teachers in Japan, where they have to Teach English for No Obvious Reason. Most Japanese students are thus reluctant to speak up even in speaking classes and are hence considered shy and unmotivated by non-Japanese teachers, whose effort to teach communicative English has failed rather miserably (Moteki 2004). Therefore, a totally different approach needs to be adopted if this pitiful situation is to be remedied at all.

Interestingly, I have recently observed a similar situation at a university in Malaysia, where I enrolled in two Malay language courses for international students. The problem that I witnessed there was that most students lacked motivation to learn Malay, not for cultural reasons, but for practical ones. As far as the students were concerned, they were there to study for their graduate degrees, such as engineering, business, medicine, etc., which they could do all in English. And yet, completing some Malay courses was a degree requirement, so they were only reluctantly attending Malay classes. Naturally, they felt that Malay was nothing but a nuisance. As a result, all they achieved, even after two semesters of Malay, was only a very limited knowledge of basic vocabulary, and even that, they quickly forgot once they were done with the Malay language courses. It was sad to see how the Malay teachers had to struggle with 
these students, to whom communicative activities were all but meaningless. The amount of the Malay language input the students had was limited only to what they heard in their Malay classes, and the amount of Malay they uttered remained an absolute minimum throughout the two semesters. No wonder their Malay never improved however long they stayed in Malaysia.

As for the problem in Japan, I have been doing something about it for the last 15 years or so and have seen some good results (e.g., Namai 2019). In what follows, therefore, I would like to turn to Malay and make some suggestions as to what might be adopted to better deal with the kind of Malay language students described above. In so doing, I will utilize my experiences of teaching English in Japan as well as my knowledge of theoretical linguistics.

\section{LITERATURE REVIEW}

Saito (2000) introduces Japanese historical figures who had an excellent command of English and explains how they achieved their remarkable feat, especially in times when there were no convenient learning materials. According to him, they mostly depended on the grammartranslation method, which was well suited to the linguistic culture of Japan. Within this culture, speakers are expected to leave the main point of their utterance unsaid, always expecting the listener to make an educational guess at it. In fact, nonverbal communication has traditionally been considered the most elegant way of conveying messages, which is still true in presentday Japan. This is why Japanese students in general find it very difficult to engage in any kind of explicit communicative activities, which are inevitably forced by CLT-based English instruction.

Moteki (2004) reports a shocking fact about the history of English education in Japan. Grammar translation prevailed in schools until the end of the 1980s, when the average TOEFL scores of Japanese people were not very good, but they were nonetheless good enough to reach the rank of number 20 or so among the 25 participating Asian countries in terms of TOEFL national average scores. Then, the Ministry of Education, Culture, Sports, Science, and Technology (MEXT) started to demand that all schools adopt CLT-based English instruction and introduced the Japan Exchange and Teaching Program (JET Program), through which it recruited native speakers of English as assistant teachers and sent them to schools all over Japan. These assistant teachers were typically young university graduates who did not have any teaching qualifications or experiences, but together with Japanese teachers of English, they taught communicative English in junior and senior high schools. Unfortunately, this triggered the declining trend of the average TOEFL scores of Japanese examinees, and Japan plummeted to the last position in the academic year of 1997/1998. Since then, Japan has been occupying the penultimate position, followed usually by North Korea. According to the latest TOEFL iBT Test and Score Data Summary (ETS 2020), Japan is still number two from the bottom, but the last position now goes to Tajikistan.

Torikai (2006) attributes the failure of CLT in Japan to traditional Japanese-style education, which is heavily influenced by Confucianism. That is, the teacher is viewed as an untouchable sage, and the students are supposed to just quietly listen to the teacher's monologue without raising any questions. If the teacher is a native speaker of English, the students feel extra psychological pressure, since they are acutely aware of the fact that they cannot express even the simplest idea in English. These facts account for the typical Japanese personality characterized by taciturnity and passivity, and it collides head-on with the philosophy behind CLT, which is all about active participation in conversational activities.

Otsu (2013) turns to CLT practitioners and shows from a cognitive linguistic perspective how misguided they are in trying to teach English to Japanese students. According to him, many CLT advocates seem to believe in the following two statements: 
1. First language acquisition and second language learning are basically the same thing.

2. Language users are familiar with what language is, how it is used, and how it can be learned.

According to Otsu, however, these statements are blatantly false. Statement 1 ignores the fact that first language acquisition simply happens to babies without them having to make any conscious efforts, whereas second language learning necessarily requires learners to make such efforts. Statement 2 is a common misconception among those who are not familiar with cognitive science or the mechanism of first language acquisition. Some people think that they know their language, but, in reality, they are not aware of any of the abstract linguistic rules that they are unconsciously following, or how their language is used in many different contexts, much less how it can be learned by those who have already passed the critical period for first language acquisition. Indeed, most people are at a loss when asked a grammatical question about their own language by a foreigner. And yet, CLT has been conducted under the assumption that these two statements are true, which immediately explains why CLT-based English instruction has always resulted in an utter and abject failure.

Abe (2017) is a comprehensive work that reveals all the problems that lie in the current teaching policy of adopting CLT-based instruction in order to promote the teaching of "communication English," a term coined by the MEXT. Abe's criticism is targeted mostly at policy makers and their professional advisers, who blindly assume that CLT must be a panacea that somehow cures Japanese students' passivity and helps them effortlessly acquire English verbal skills that are good enough for working in the international arena without any serious problems. Like Otsu, Abe points to the importance of distinguishing first language acquisition and second language learning. Since Japanese students are all second language learners, they need specific grammar instruction. He also argues for the necessity of such instruction in light of the limited time allotted for English education in Japan, which is only three to five 50-minute classes a week. Unlike CLT, which has not done any good to Japanese students, grammar translation at least can lay, even under the time constraint, the foundation of English for those who decide to pursue conversational English later in their lives.

Erikawa (2018) may be the definitive work against continuing CLT-based instruction in Japanese schools. In this 473-page-long book, the author offers quite a few robust criticisms against the MEXT's enforcement of communication English in school classrooms. In the 1990s, English textbooks authorized by the MEXT all became thinner, as the newly introduced CLT-based instruction mainly required conversational activities. As a result, most high school students' English reading skills dropped drastically. Before the introduction of CLT, Japanese students, who typically lacked good conversational skills of English, still had decent reading skills of the language. With the adoption of CLT, however, they started to lose those skills, while their conversational skills remained bare minimum. As Erikawa suggests, using even more CLT-based instruction to redress this rather unfortunate situation does seem absurd, indeed.

\section{METHODOLOGY}

This study is based on a comparative analysis between the Malay language learning culture at a university in Malaysia and the English learning culture that pervades Japan. Observation of Malay language classes was carried out in two Malay language courses for international students at the National University of Malaysia during the Fall Semester of 2017 and the Spring 
Semester of 2018. The teaching method employed in these classes and the progress, or lack thereof, of the attending students were examined in terms of learners' motivation, teaching methodology, and L2 learners' general inability to capture any grammatical principles without explicit, systematic instruction. This was done for the purpose of finding more effective teaching activities in Malay as a Foreign Language classes. For the evaluation of the syntactic explanation of Malay sentences offered in the observed classes as well as the grammatical description of those sentences in the Malay language textbook used, Chomsky's (1986) theoretical framework of generative grammar was adopted.

\section{RESULTS AND DISCUSSION}

\section{New Language Circuit}

When students are culturally quiet or unmotivated to learn a foreign language for whatever reason, forcing them to engage in student-centered activities is simply unrealistic. What should be done instead is to constantly guide them through oral activities that do not require a lot of thinking. Keeping them busy with many passive but fun activities is the key to success. In this way, students will gradually develop a new language circuit in their brains that allows them to understand the Malay language more easily. This circuit is indispensable if they choose to become good speakers of Malay later on.

\section{Different Use of Muscles}

Different languages have different phonological rules, including phonotactics. For example, English allows consonant clusters, such as the first three sounds of a single-syllable word spring, but Japanese generally does not. In fact, spring is rendered /supuriNgu/ in Japanese, where $/ \mathrm{N} /$ represents a syllabic nasal consonant. Notice that all the other consonants are followed by a vowel, making spring a five-syllable word. This open syllable rule is the most basic phonological rule of Japanese, so Japanese speakers find it difficult to pronounce any kind of consonant cluster, the pronunciation of which necessarily requires different use of articulators, that is, vocal organ muscles. In fact, everybody encounters this kind of problem when learning a foreign language. The only way to solve it is to have a lot of physiological training in the form of a pronunciation exercise. Unfortunately, however, this is where many language classes fall short, especially those that adopt CLT.

In the case of Malay, a word like empat (which means 'four') is difficult to pronounce for speakers of a language that does not have many vowel sounds. Japanese is said to have only five vowels, namely, /a/, /i/, /u/, /e/, and /o/. But the first vowel of empat is $/ \Lambda /$, which is a stressed schwa /ə/, and this sound is missing in the Japanese vowel inventory. So, speakers of Japanese tend to replace it with $/ \mathrm{u} /$, ending up saying umpat, which has a totally different meaning ('swear') from that of empat. Moreover, Japanese lacks consonants equivalent to /1/ and $/ \mathrm{r} /$, so a Malay word like berpeluh, which contains $/ \mathrm{\partial} /, / \mathrm{u} /, / \mathrm{r} /$, and $/ 1 /$, is extremely difficult to pronounce for Japanese speakers.

What should we do? In this regard, let me introduce pronunciation exercises that I have been using when teaching English to Japanese students. This may help Malay teachers to design similar exercises to better serve the needs of their students.

Tongue twisters

First, I explain to my students that pronunciation exercises are just tongue twisters. Since 
students know that tongue twisters are a fun activity that requires no cognitive strain, they always enjoy doing them. (1) and (2) are two popular examples.

(1) red lorry, yellow lorry

(2) six thin things

As for (1), after explaining how to produce /r/ and /1/, I make students say it quickly and repeatedly. (2) is an especially important tongue twister for Japanese students. The combination of $/ \mathrm{s} /$ and $/ \mathrm{i} /$ does not exist in the Japanese language; the phonotactics of the language necessarily changes /s/ into / $/$ / when followed by /i/, so Japanese students tend to say / $\mathrm{jiks} /$ for six. Likewise, the $/ \theta /$ sound is lacking in Japanese, so thin and things are often realized as $/ \mathrm{Jin} /$ and / $\mathrm{jinz} /$, respectively. Notice that an innocent expression like Please sit down contains the sound sequence of /si/. Saying umpat for empat is awkward enough. It is even more awkward — and embarrassing - to say Please shit down! This kind of embarrassment can be avoided if Japanese students practice a tongue twister like (2) repeatedly.

Reading Aloud and Beyond

The following discussion assumes availability of a language textbook that is accompanied by audio files (or CDs) of all its passages recorded by native speakers.

To see whether a student is actually making any progress in his/her target language, all you need to do is to have the student read aloud a simple text written in that language. You will be surprised to know that you can immediately tell how much progress, if any, the student is making.

This is a very important fact. Being able to read aloud well may not be a sufficient condition for mastering a foreign language, but it is certainly a necessary condition, especially in classroom settings. Besides, there are other positive effects in reading aloud, which will be explained shortly, so plenty of time should be allotted for this simple but effective exercise.

Take, for example, a small English dialog like (3).

(3) A: What are you going to do tomorrow?

B: I'm going to visit my uncle tomorrow.

In ordinary conversation, the combination of what and are is usually realized as /waro/, where $/ \mathrm{s} /$ is a flap sound, distinct from $/ \mathrm{t} /$. Moreover, going to is often rendered gonna, so what we actually hear in (3A) is /warəyəgənədu/, which is very different from what are you going to do. Likewise, the utterance in (3B) is pronounced as I'm gonna visit my uncle, which naturally puzzles beginning students of English. However, if students are taught these particular sound changes and practice saying them, then they will easily understand dialogs like (3) when they hear them in the future, an obvious merit of reading aloud.

Knowledge of sentence structure

Becoming good at reading aloud presupposes the knowledge of the structure of any given sentence, and in this sense too, reading aloud, which necessarily makes students sensitive to language structure, is an important exercise. In this regard, consider the following Malay dialog (Othman et al. 2012: 123).

(4) A: Saya suka berenang dan main badminton.

B: Saya juga suka berenang. Kita boleh pergi berenang bersama-sama. 
A: Bagus cadangan awak. Minggu hadapan kita boleh pergi berenang di kompleks sukan universiti.

B: Baiklah.

A: Saya akan jumpa awak di padang petang nanti.

B: Ya. Kita jumpa di sana.

Take the last utterance by A. The verb phrase, jumpa awak di padang petang nanti, has the internal structure given in (5a-b).

a. [[jumpa awak] [di padang]] [petang nanti]]

b.

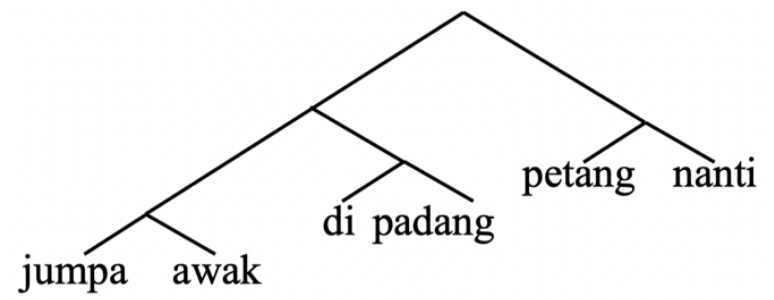

As is clear in (5a), di and padang form a unit (prepositional phrase), and so do petang and nanti (noun phrase). And as units, they each modify jumpa awak, thus forming the entire verb phrase, as shown by the tree diagram in (5b). Therefore, it is possible to place a pause before di padang and before petang nanti, since those positions are phrase breaks. And yet, students who do not know the internal structure of this verb phrase will randomly place a pause, say, before padang or before nanti, suggesting the wrong structures in (6a-b).

(6) a. [jumpa awak di] [padang petang nanti]

b. [jumpa awak] [di padang petang] [nanti]

For this reason, it is essential to first provide students with an accurate structural analysis of any sentence (see section 3) and guide them to pronounce the sentence with the right intonation plus correct placement of pauses. Read-aloud practice then reinforces students' knowledge of the right structure of the sentence.

Shadowing

Once reading aloud is sufficiently done, it is time to move onto the oral exercise known as "shadowing." Shadowing is similar to reading aloud, but it requires audio files (or CDs) of narrations recorded by native speakers. Students are to listen to these narrations without looking at the corresponding texts and parrot out loud what they hear as they listen. This is called shadowing, which is a passive activity on a par with reading aloud in that students don't have to create any sentences on their own. But in order to shadow well, they must do a lot of read-aloud practice first and make sure that they can read as fast as the native speakers on the audio files. In that sense, shadowing is more difficult than reading aloud, since students can never control the speed of their speech as they shadow; they simply have to keep up with the speed of what they hear. Reading aloud can and should be practiced in the classroom with the help of the teacher. In contrast, practice of shadowing should be assigned as homework for practical reasons; there are individual differences as to how quickly students can feel confident in performing shadowing. Hence, students should be allowed to practice as much as they want at home, at their own pace. At the end of every class, however, the teacher should check how well they can shadow, one student at a time. 
One advantage of this individual checking is that there is no room for cheating. If students don't practice at home, it inevitably shows when they perform in front of the teacher. Poor performance immediately makes students realize the importance of practice, urging them to do shadowing homework without fail. In this way, the teacher can virtually control how students use their time even outside the classroom. On the other hand, when students' performance is good, it directly gives them confidence, further motivating them to practice their target language even more.

\section{Reproduction}

The final stage of this line of practice is "reproduction." The teacher first designates important sentences of any length for students to reproduce. The teacher then pronounces each of them, and students repeat after the teacher. Unlike shadowing, students must wait until they hear the whole sentence before they open their mouth. The rationale behind this activity is that if students can read and understand certain sentences, they should be able to say them without looking at anything. At this point, the teacher should point out to students that they can easily do this if they are to do it in their first language.

Reproduction can be done step by step. For instance, the teacher first writes an important sentence on the blackboard for everyone to see. Then, bit by bit, the teacher erases the sentence, as shown in (7) ((7a) is from Zarina et al. 2012: 154).
a. Saya mahu mendaftar kursus
b.
mahu mendaftar kursus
tetapi saya tidak tahu
caranya.
c. mahu
tetapi saya tidak tahu
caranya
d. mahu
kursus
tetapi saya tidak
caranya
e. mahu
tetapi saya tidak
d.
tetapi

At first, students see the whole sentence, as in (7a), and read it out loud after hearing the teacher's model pronunciation. Then, they see less and less, as in (7b) to (7e), but reproduce (7a) by providing the missing words on their own. In the end, they should be able to say the whole sentence without looking at anything, i.e., (7d). But making sure that students can read aloud (7a) well is a prerequisite for starting this exercise, of course. It is only after that that they are ready to start reproducing what they hear.

\section{Vocabulary Building}

\section{Instant response}

With the advent of ICT in education, there are now many useful computer programs available to schoolteachers, including language teachers. Flash card applications are one good example. Being able to speak a foreign language requires an instant response to any linguistic stimulus, and in this respect, vocabulary building activities using digital flash cards come in very handy. A teacher of Malay, for example, might want to show new Malay words on digital cards one by one in the classroom and ask each student to give their definitions in English right away. When a student gives a wrong answer or cannot answer within a few seconds, the teacher immediately asks the next student. This process is repeated several times until someone gives all the correct answers without hesitation. After that, the same activity is conducted using the English side of each card so that students must come up with the right Malay word each time and do so quickly. 
"Karuta" game

There is a traditional Japanese game called "karuta," and it can be adopted as a vocabularybuilding game as well. What the teacher needs to prepare is a set of paper cards with target words written on them. Then, the teacher places those cards on a table, around which students stand. In the case of a Malay language class too, about 50 cards with different Malay words written on them may be placed on the table. Then, one by one, the teacher reads out English translations, and students compete to grab the Malay cards that correspond to the English words. In this activity, students can easily get excited, and they will have a lot of fun learning Malay words. Now let's move onto grammar.

\section{Knowledge of Grammar}

In language classes that adopt CLT, not much time is spent on grammar teaching. This may be fine if the objective of the language class is only oral communication. In such a class, an utterance like Me no money, meaning "I don't have money," may be accepted, since it can certainly convey what its speaker intends to convey. Indeed, this is much better than being totally quiet, a characteristic of many Japanese students in English classes, as was noted earlier. And yet, this is not what good students usually expect from language classes. They want to learn accurate English and want to be corrected if they say anything incorrect. In other words, just as babies search, albeit unconsciously, for systematic sentence patterns in their L1 input, adult L2 learners too wish to follow hidden grammatical rules and expect their teachers to teach them those rules. With this much in mind, I will now point out some of the grammatical rules that I personally think should be taught in Malay classes for international students.

\section{Phrasal Constituent}

It goes without saying that beginning learners of Malay do not know anything about the language. When they first hear an utterance as simple as saya jumpa bapa guru, they not only cannot figure out what it means, but also have no idea what the subject is, where the main verb is, or even how many words there are in the sentence. Even if they somehow find that bapa guru is a unit, with bapa meaning 'father' and guru 'teacher,' they still do not know whether it means 'Father's teacher' or 'Teacher's father' or even 'Father is a teacher.' This shows how important the knowledge of syntactic structure is in L2 learning, in addition to the knowledge of vocabulary. However, user-friendly explanation of syntactic rules is often missing in the teaching of Malay. In this respect, look at the following wh-questions.

(8) a. Berapa haribulan hari ini?

b. Berapa umur bapa awak?

c. Berapa harga baju itu?

On the surface, these questions look structurally identical, and this is exactly the impression that students get from them. One characteristic of Malay is that subject and predicate are often reversible, so the declarative sentence in (9a) below may be rephrased as (9b) (see the dialog in (4) above), without much of a semantic change.

(9) a. Cadangan awak bagus.

b. Bagus cadangan awak. 
This is true of questions as well. In fact, (8a) may be said as (10) below, especially under informal circumstances; in terms of meaning, however, (8a) and (10) are the same in all relevant respects.

(10) Hari ini berapa haribulan?

Now, given (10), students will simply assume that (8b) and (8c) can also be restructured as (11a) and (11b), without knowing that the resulting sentences are ungrammatical.

(11) a. *Bapa awak berapa umur?

b. *Baju itu berapa harga?

To their surprise, the correct forms are (12a-b).

(12) a. Umur bapa awak berapa?

b. Harga baju itu berapa?

This means that the three wh-questions in (8) do not share the same syntactic structure. (8a)'s internal structure is as in (13a), but (8b) and (8c) have the structures in (13b) and (13c), respectively. That is, haribulan forms a phrasal constituent with berapa in (8a), whereas umur and harga do with what follows them, namely bapa awak and baju itu in (8b) and (8c), respectively.

(13) a. [berapa haribulan] [hari ini]

b. [berapa] [umur bapa awak]

c. [berapa] [harga baju itu]

This kind of fact needs to be explicitly taught to students, who typically have no idea about the syntactic structure of any Malay sentence. Otherwise, they cannot be blamed even if they produce ungrammatical sentences like (11a-b).

The importance of accurately grasping phrasal constituents can also be made clear in analyzing a noun phrase pair like (14a-b).

(14) a. umur bapa kawan guru saya

b. umur bapa guru sains saya

In Malay, attributive modifiers are generally postmodifiers, so in the case of (14a), saya modifies guru, forming a noun phrase that means 'my teacher.' Then, this noun phrase modifies kawan, making a bigger noun phrase 'my teacher's friend,' which in turn modifies bapa, making an even bigger noun phrase meaning 'my teacher's friend's father.' Finally, the noun phrase thus created modifies umur, completing the whole phrase with the meaning of 'my teacher's friend's father's age.' But this explanation does not always work, since in (14b), saya does not form a constituent with the noun that immediately precedes it, namely sains. Here, sains forms a noun phrase with guru, and it is this phrase that saya modifies.

In order to clearly show to students this difference between (14a) and (14b), the concept of phrasal constituent is indispensable. The crucial difference lies between the parts kawan guru saya and guru sains saya, whose structures may be represented as (15a-b), respectively. 

(15) a. [kawan [guru saya]]
b. [[guru sains] saya]

Notice that the bracketing in (15a) clearly indicates the phrasal constituent of guru saya 'my teacher.' Then, as a unit, this phrase modifies kawan from behind, creating a phrase with the meaning of 'my teacher's friend.' As for (15b), the bracketing shows that sains first modifies guru, forming a noun phrase that means 'science teacher' and that saya subsequently modifies this noun phrase, creating a phrase that means 'my science teacher.' Thus, from this bracketing convention, students will be able to clearly see the structural difference between (14a) and (14b) rather straightforwardly.

\section{Syntactic Categories}

There are many syntactic restrictions even in the basic grammar of Malay that cannot be taught without mentioning syntactic categories (or "parts of speech" in traditional grammar). Unfortunately, however, this is where many Malay classes leave something to be desired, often making students feel confused and puzzled in trying to figure out grammatical rules. In what follows, some examples are given, and it is hoped that more teachers will start to provide explanations along these lines based on syntactic categories.

\section{Negation}

The first example is from negation. Look at (16), where the addition of tidak in front of the predicate makes each sentence negative.

(16) a. Saya suka gula. $\rightarrow$ Saya tidak suka gula.

b. Saya tonton TV. $\rightarrow$ Saya tidak tonton TV.

c. Saya lapar. $\quad \rightarrow \quad$ Saya tidak lapar.

However, this rule does not work in the following cases:

(17) a. Saya dari Tokyo. $\quad \rightarrow \quad$ *Saya tidak dari Tokyo.

b. Saya pelajar bahasa. $\rightarrow$ *Saya tidak pelajar bahasa.

Here, the resulting sentences are ungrammatical with tidak; for grammatical sentences, bukan must be used, instead:

(18) a. Saya bukan dari Tokyo.

b. Saya bukan pelajar bahasa.

What is going on? The easiest way to explain this is to say that bukan is used when negating a sentence whose predicate is either a prepositional phrase, such as dari Tokyo, or a noun phase, such as pelajar bahasa. Tidak is used for all the other types of predicate.

Premodifiers

The second example comes from a set of premodifiers. As was mentioned in the previous section, Malay modifiers are generally postmodifiers, such as baik, saya, and itu in (19a-c).

(19) a. kawan baik 

b. kawan saya
c. kawan itu

This much is usually taught in Malay classes. However, the following exceptions, where correct forms are given in parentheses, are often taken for granted:
(20) a. *kawan tiga
(tiga kawan)
b. *kawan ramai
(ramai kawan)
c. *kawan beberapa
(beberapa kawan)

Students want to know why words like tiga, ramai, and beberapa are not postmodifiers here. Crucially, they are all quantifiers, having to do with either number or quantity. In that sense, they form a natural class, excluding other category types like adjective and noun. And quantifiers are premodifiers in Malay, just like those in English. This fact must be specifically taught in class in order to help students avoid making errors like (20a-c).

\section{Determiners}

The third example is about determiners, which are either demonstrative pronouns, such as ini and itu, or personal pronouns, such as saya and dia. Look at (21) and (22).
(21) a. baju merah
b. baju itu
c. baju merah itu
d. *baju itu merah
(22) a. baju hitam
b. baju dia
c. baju hitam dia
d. *baju dia hitam

As (21a) and (21b) show, baju can be modified either by merah or by itu. Baju can also be modified by these two postmodifiers one after the other, as in $(21 \mathrm{c})$. However, there is a hidden rule here that says merah cannot modify baju if itu first modifies it, as shown in (21d). (21d) is grammatical only as a sentence with the meaning of 'That shirt is red,' but it can never be understood as a noun phrase that means 'that shirt which is red.' This points to the fact that if a determiner modifies a noun, it is no longer possible to modify the noun from outside the determiner. (22a-d) show that the personal pronoun dia works exactly like itu. In that sense, personal pronouns are on a par with determiners. In fact, they too are often classified as determiners in generative grammar (e.g., Radford 2009). (Between a demonstrative pronoun and a personal pronoun (and ordinary noun), the latter always takes precedence in modification, meaning that it must modify the noun before any demonstrative pronoun; hence, baju dia itu is fine, but *baju itu dia is not.) At any rate, this language-specific rule must also be explained, since in other languages like Japanese, noun phrases corresponding to (21c-d) and (22c-d) are all grammatical, inviting Japanese learners of Malay to construct ungrammatical forms like (21d) and (22d).

\section{Adjectives}

The fourth example is about adjectives in Malay. Adjectives typically have two uses: attributive use and predicative use. In this respect, look at how the adjective baik is used in (23a-b). (23) a. Saya ada kawan baik.
b. Kawan saya baik.
(Attributive use)

(Predicative use) 
Baik in (23a) directly modifies kawan as a postmodifier, and this use is called attributive use. On the other hand, baik in (23b) is the predicate of the sentence that means 'My friend is good.' Hence, this use is called predicative use.

What is peculiar about Malay adjectives is that the syntactic distribution of their comparative and superlative forms is limited only to predicate positions. First, look at English examples in (24) and (25).

(24) a. a better car.

(Attributive use)

b. Your car is better.

(Predicative use)

(25) a. my best friend.

(Attributive use)

b. My friend is (the) best.

(Predicative use)

These examples show that the comparative form better and the superlative form best can be used either attributively or predicatively. But this is not the case with Malay counterparts. Look at (26) and (27).

(26) a. Kereta dia lebih baik.

b. *kereta lebih baik dia (intended: 'his better car')

(27) a. Kawan saya paling baik.

b. *kawan paling baik saya (intended: 'my best friend')

The comparative form lebih baik and the superlative form paling baik can be used only predicatively, as in (26a) and (27a). They can never be used attributively, as shown in (26b) and $(27 b)$, which are both ungrammatical. This fact too is often overlooked in Malay instruction, but it really needs to be explained to students, who would otherwise say things like * Kawan paling baik saya akan datang ke KL when trying to say in Malay 'My best friend will come to KL.' This may be all too obvious to native speakers of Malay, but learners of Malay do not even have a clue.

\section{CONCLUSION}

Teaching a foreign language to unmotivated students, as well as quiet students, is a difficult task. In teaching these students, CLT is not useful, because it specifically requires students' voluntary participation in student-centered activities, in which the teacher's role is generally seen only as the "manager of learning" (Leather 2001: 233) who has "no specially privileged position" (ibid.). In order to train the kinds of students in question, strong leadership is hence required of teachers. In fact, teachers should be able to constantly lead their students to engage in effective classroom activities, that is to say, mechanical activities that do not demand too much will power on the part of the students but nonetheless help them develop a new language circuit in their brain.

No language teacher wishes to make their students feel puzzled or confused about their target language. In order to avoid this potential problem, teachers need to know, and must be ready to explain, important grammar rules in a student-friendly fashion. Imagine having to play chess without knowing its rules, which is comparable to the situation that adult language learners face should no grammar instruction be provided for them. Let's face it. Most L2 learners have already passed their critical period for language acquisition, during which they could have developed the grammatical system of any language in the world without doing anything special (Jackendoff 1994). Therefore, grammar rules must be explicitly taught to them, and ignoring this important aspect of L2 learning inevitably results in a failure. I believe 
that this is the last thing any responsible language teacher wants to see.

\section{ACKNOWLEDGEMENTS}

This paper was made possible by my stay as a visiting professor at Pusat Pengajian Citra Universiti, Universiti Kebangsaan Malaysia in 2017-2018. I would like to thank all the fine people of Pusat Citra as well as everybody else that I met at UKM for providing me with quite a few educational opportunities in addition to a very comfortable work environment.

\section{REFERENCES}

Abe, M. 2017. Sizyosaiaku-no eigoseisaku: uso-darake-no yonginoukanban [English education in chaos: confusion and dishonesty in Japanese government policy]. Tokyo: Hituzi Syobo.

Abott, G. 1981. Encouraging communication in English: A paradox. ELT Journal 35 (3): 228230.

Bax, S. 2003. The end of CLT: A context approach to language teaching. ELT Journal 57 (3): 278-287.

Chomsky, N. 1986. Knowledge of language: Its nature, origin, and use. New York: Praeger.

ETS. 2020. TOEFL iBT Test and Score Data Summary 2020. https://originwww.ets.org/s/toefl/pdf/toefl_tsds_data_2020.pdf (Accessed 1 October 2021).

Erikawa, H. 2018. Nihon-no gaikokugokyōikuseisaku-si [A historical study offoreign language education policy in Japan]. Tokyo: Hituzi Syobo.

Jackendoff, R. 1994. Patterns in the mind: Language and human nature. New York: Basic Books.

Leather, S. 2001. Training across cultures: content, process, and dialog. ELT Journal 55 (3): 228-237.

Moteki, H. 2004. Monkasyo-ga eigo-o kowasu [The MEXT destroys English]. Tokyo: Chūōkōronshinsha.

Namai, K. 2019. An Eastern way to overcome L2 anxiety. Journal of Applied Languages and Linguistics 3 (2): 161-174.

Othman, Z, R. Hashim, and R. Abdullah. 2012. Modul komunikasi bahasa Melayu antarabangsa. Bangi: UKM Press.

Otsu, Y. 2013. Eigokyōikusseisaku-wa naze matigau-no-ka [Why English education policies go wrong]. In Eigokyoiku, semarikuru hatan [English language education in danger], ed. Yukio Otsu, Haruo Erikawa, Yoshifumi Saito, and Kumiko Torikai, 51-72. Tokyo: Hituzi Syobo.

Radford, A. 2009. An introduction to English sentence structure. Cambridge: Cambridge University Press.

Saito, Y. 2000. Nihonjin-ni Itiban Atta Eigogakusyuhō [The English Learning Method Best Suited to the Japanese]. Tokyo: Shodensha.

Torikai, K. 2006. Zizokukanō-na mirai-e-no komyunikēsyon kyōiku [Sustainable communication education in the future]. In Nihon-no eigokyoiku-ni hituyō-na koto [What is required in English language education in Japan], ed. Yukio Otsu, 135-151. Tokyo: Keio University Press. 


\section{KENICHI NAMAI}

Waseda University,

Shinjuku City, Tokyo, Japan

*Corresponding author: ken11a@,waseda.jp

Received: 17 July 2021 / Accepted: 15 October 2021 / Published: 20 November 2021 